\title{
Influence of Microcystin-LR on the activity of membrane enzymes in rat intestinal mucosa
}

\author{
I. M. Moreno, A. Mate ${ }^{1}$, G. Repetto, C. M. Vázquez ${ }^{1}$ and A. M. Cameán \\ Departamentos de Bioquímica y Toxicología and ${ }^{1}$ Fisiología y Zoología, Facultad de \\ Farmacia, Universidad de Sevilla, C/Tramontana s/n, 41012 Sevilla, Spain
}

(Received on March 27, 2003)

I. M. MORENO, A. MATE, G. REPETTO, C. M. VÁZQUEZ and A. M. CAMEÁN. Influence of Microcystin-LR on the activity of membrane enzymes in rat intestinal mucosa. J. Physiol. Biochem., 59 (4), 293-300, 2003.

The objective of the present study was to evaluate the effects of microcystin-LR (MCLR) on the activity of membrane enzymes from intestinal mucosa. In addition, serum chemistry and peroxidative status of both serum and intestinal homogenate were evaluated after treatment with MCLR. Wistar rats were treated with intraperitoneal injection of either $100 \mu \mathrm{g}$ pure MCLR/Kg body weight or saline solution. A significant increase in liver weight and altered serum enzyme activities were found in MCLR-treated rats, indicating damage to the liver in these rats, as previously suggested. A higher specific activity of sucrase (1.5-fold) was observed after the administration of MCLR, whereas other intestinal apical membrane enzymes, such as lactase, maltase and alkaline phosphatase were not modified by the treatment. The specific activities of acid phosphatase and succinate dehydrogenase, markers for lysosomal and mitochondrial membranes, respectively, were also increased (32\% and $60 \%$, respectively) in treated rats. The analysis of lipid peroxidation showed that the peroxidative status was increased in both serum and intestinal mucosa from MCLRtreated rats, reflecting an excess production of oxygen free radicals induced by this cyanobacterial toxin. In conclusion, this study shows that acute exposure to MCLR affects the intestinal physiology by modifying the intestinal peroxidation status as well as the activity of membrane enzymes.

Key words: Microcystin-LR, Intestine, Rat, Membrane enzymes.

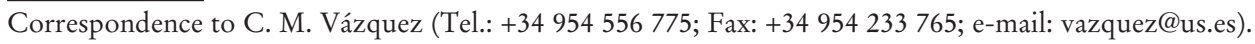


Microcystins (MCs) constitute a group of related cyclic heptapeptide toxins produced by cyanobacteria blooming in nutrient-enriched reservoirs and lakes. There are a lot of different analogues of MCs, being microcystin-LR (MCLR), in acute terms, one of the most potent MCs. This microcystin is a potent hepatotoxin that accumulates in the liver, disrupting sinusoidal endothelial cells and causing hemorrhagic shock and rapid death in mice (17), rats (19), and fish (15). In addition, previous studies have showed that exposure to MCLR may cause renal toxic effects, including histopathological changes and modifications in the kidney functional parameters in rats (20) and fish (15). However, renal damage rarely occurs in mice.

It is accepted that the cellular uptake of MCLR is mediated by a bile acid carrier system present in hepatocytes (22). These low molecular weight toxins act as strong inhibitors of protein phosphatases 1 and $2 \mathrm{~A}$, which regulate numerous biological process, leading to an increase of protein phosphorylation in the cell (12).

Experiments carried out to determine the LD50 for MCLR have shown that this parameter strongly depends on the administration route followed. Furthermore, there are also interspecies differences in the susceptibility to the acute effects of the toxin (16). Previous studies in rats have shown that the LD50 $(25 \mathrm{hr}$, intraperitoneal injection) for MCLR was $122 \mu \mathrm{g} / \mathrm{Kg}$ body weight (19).

There are several papers in the literature regarding the influence of MCs on liver and kidney. However, little attention has been paid to the effects of these cyanobacterial toxins on the intestine (8). In a previous work, the small intestine has been considered as the main route of MCLR absorption (13), suggesting the ileum as the specific place of absorption.
This study was designed to evaluate the acute toxicity of MC-LR on the small intestine. Rats were used and a single acute dose of intraperitoneal injection was chosen, due to the cost of pure microcystin-LR. The activity of several membrane enzymes and peroxidation levels were determined in the intestinal mucosa following exposure to MCLR. In addition, serum chemistry and lipid peroxidation levels were also evaluated.

\section{Materials and Methods}

Chemicals.- Cyanobacterial toxin Microcystin-LR (994 g/mol, purity > 95\%) was obtained from Calbiochem (La Jolla, CA, USA). Working solutions were prepared and the correct dosing concentration was confirmed by HPLC with UV detection, using a Varian model 9012 chromatograph equipped with a Varian model 9050 UV detector (4). All chemicals were supplied by Sigma (Madrid, Spain), except for the reagents used for the protein determination, which were from BioRad (Barcelona, Spain).

Animals and treatments.- Male Wistar rats weighing about $200 \mathrm{~g}$ were kept for a week before using in a well-ventilated room maintained at $22 \pm 2{ }^{\circ} \mathrm{C}$ on a 12 hour light / 12-hour dark cycle, with free access to water and commercial laboratory animal ration (Panlab SL). Rats were randomly assigned into two groups, which were administered with intraperitoneal injection of either MCLR (at a dose of $100 \mu \mathrm{g} / \mathrm{Kg}$ body weight) or the same volume of vehicle $(0.9 \%$, w/v saline solution). After 8 hours, animals were killed by ether inhalation. Blood was collected by cardiac puncture, and serum was separated $(1500 \mathrm{~g}$ for $10 \mathrm{~min}$ ) and stored at $-20{ }^{\circ} \mathrm{C}$ for subsequent analysis. Liver and 
small intestine (jejunum and ileum) were quickly excised, rinsed with ice-cold $0.9 \%$ $(\mathrm{w} / \mathrm{v})$ saline solution and weighed. Animal care and the study plan followed the local standard for protecting animal welfare.

Enzyme assays.- For the determination of intestinal enzyme activities, the small intestine was opened along its mesenteric border; then the mucosa was scraped from the underlying layer with a glass slide, frozen in liquid nitrogen and kept at $-80^{\circ} \mathrm{C}$ until used. Mucosal scrapings were homogenized at $4{ }^{\circ} \mathrm{C}$ in a buffer containing $100 \mathrm{mmol} / \mathrm{L}$ mannitol, $2 \mathrm{mmol} / \mathrm{L}$ HEPES/Tris, pH 7.1, $0.1 \mathrm{mmol} / \mathrm{L}$ benzamidine and $0.2 \mathrm{mmol} / \mathrm{L}$ phenylmethylsulfonyl fluoride, using a Waring Blender at maximum speed for $30 \mathrm{~s}$. The activities of the apical membrane enzymes, sucrase, lactase and maltase in the intestinal mucosal homogenates were measured by DAHLQVIST method (5), whereas alkaline phosphatase was estimated by BRETAUDIERE method (3). Acid phosphatase, as a marker enzyme of lysosomal membranes, and succinate dehydrogenase, as a marker of mitochondrial membranes, were also determined as previously described $(1,21)$. Protein was measured by Coomassie Brilliant Blue protein assay using bovine gamma-globulin as standard (2). All assays were measured using U2001 Hitachi spectrophotometer (USA).

Serum determinations were performed by Ektachem 900 autoanalyzer (Izasa SA, Barcelona, Spain). The following parameters were measured: alkaline phosphatase (ALP), aspartate aminotransferase (AST), alanine aminotransferase (ALT), gammaglutamyl transpeptidase $(\gamma-\mathrm{GTP})$, lactate dehydrogenase (LDH), glucose, total cholesterol, triglycerides, albumin, total protein, creatinine, uric acid, blood urea nitrogen (BUN), sodium, potassium, calcium, phosphorus, and chlorine.
Measurement of lipid peroxidation levels.- Lipid peroxidation status was estimated by measuring the levels of malondialdehyde (MDA) in homogenized intestinal mucosa and serum samples, according to the procedure described for thiobarbituric acid reactive susbtances (TBARS) (7). Briefly, $0.5 \mathrm{~mL}$ of sample, previously treated with $25 \mu \mathrm{L}$ of $1 \%(\mathrm{w} / \mathrm{v})$ butylated hydroxytoluene in glacial acetic acid, were mixed with $0.2 \mathrm{~mL}$ of $8 \%(\mathrm{w} / \mathrm{v})$ sodium lauryl sulphate, $1 \mathrm{~mL}$ of $20 \%$ (v/v) acetic acid and $1 \mathrm{~mL}$ of $0.8 \%(\mathrm{w} / \mathrm{v}) 2$-thiobarbituric acid. The mixture was heated at 95 ${ }^{\circ} \mathrm{C}$ for $30 \mathrm{~min}$, and the resulting chromogen was extracted with $3 \mathrm{~mL}$ of n-butyl alcohol. After centrifugation (10 min at $4000 \mathrm{rpm}$ ), the absorbance of the organic phase was determined at 532 $\mathrm{nm}$. To prepare the standard curve, several dilutions of 1,1,3,3-tetraethoxypropane were processed in the same manner as the samples.

Statistical analysis.- All values are presented as mean \pm SEM. Comparison between different experimental groups was analyzed by the unpaired, two-tailed Student's t-test, and differences were considered significant at $\mathrm{P}<0.05$.

\section{Results}

Serum chemistry.- Significant changes in serum enzymes were observed in animals treated with microcystin-LR at a dose of $100 \mu \mathrm{g} / \mathrm{Kg}$ body weight (Table I). The levels of ALP, AST, ALT, and LDH were higher in MCLR-treated than in control rats (1.9, 8.5, 22 and 3.8-fold, respectively). In contrast, no significant differences were observed in $\gamma$-GTP levels between both groups of animals. On the other hand, treated rats showed higher 
levels of serum glucose and BUN, and lower levels of total cholesterol, triglycerides, albumin, total protein and uric acid, whereas creatinine levels were not altered by the treatment. Studies on electrolyte levels detected a significant decrease in sodium, potassium, calcium and phosphorus in MCLR-administered rats. Chloride levels were also diminished, although not significantly.

Intestinal enzyme activities.- Studies on enzyme specific activities in intestinal mucosa homogenates are shown in Table II. Sucrase activity was increased significantly in treated rats, whereas activities of

Table I. Composition, enzyme activities and lipid peroxidation level in serum from control and MCLR-treated rats.

\begin{tabular}{lcc}
\hline Parameter & Control & MCLR-treated \\
\hline Glucose $^{\mathrm{b}}$ & $69 \pm 1$ & $101 \pm 4^{\star \star \star}$ \\
Cholesterol $^{\mathrm{b}}$ & $86 \pm 5$ & $60 \pm 5^{\star \star}$ \\
Triglycerides $^{\mathrm{b}}$ & $65 \pm 7$ & $39 \pm 1^{\star \star}$ \\
Albumin $^{\mathrm{b}}$ & $2210 \pm 315$ & $1407 \pm 126^{\star}$ \\
Protein $^{\mathrm{b}}$ & $6623 \pm 307$ & $5514 \pm 210^{\star}$ \\
Creatinine $^{\mathrm{b}}$ & $0.7 \pm 0.1$ & $0.6 \pm 0.1$ \\
Uric acid $^{\mathrm{b}}$ & $1.9 \pm 0.2$ & $0.9 \pm 0.1^{\star \star}$ \\
BUN $^{\mathrm{b}}$ & $24 \pm 2$ & $49 \pm 3^{\star \star \star}$ \\
Sodium $^{\mathrm{c}}$ & $148 \pm 1$ & $142 \pm 1^{\star \star}$ \\
Potassium $^{\mathrm{c}}$ & $5.1 \pm 0.3$ & $3.9 \pm 0.2^{\star \star}$ \\
Calcium $^{\mathrm{b}}$ & $10.3 \pm 0.3$ & $8.5 \pm 0.3^{\star \star}$ \\
Phosphorus $^{\mathrm{b}}$ & $15.1 \pm 0.4$ & $8.1 \pm 0.4^{\star \star \star}$ \\
Chlorine $^{\mathrm{c}}$ & $104 \pm 1$ & $101 \pm 1$ \\
ALP $^{\mathrm{a}}$ & $355 \pm 29$ & $676 \pm 76^{\star \star}$ \\
AST $^{\mathrm{a}}$ & $225 \pm 42$ & $1921 \pm 131^{\star \star *}$ \\
ALT $^{\mathrm{a}}$ & $34 \pm 3$ & $732 \pm 77^{\star \star *}$ \\
$\gamma^{- \text {GTP }^{a}}$ & $4 \pm 0.3$ & $4 \pm 0.3$ \\
LDH $^{\mathrm{a}}$ & $2811 \pm 70$ & $10745 \pm 326^{\star \star \star}$ \\
MDA $^{\mathrm{d}}$ & $10 \pm 0.8$ & $20 \pm 1.8^{\star \star \star}$ \\
\hline
\end{tabular}

Values are means \pm SE for six animals, and are expressed in ${ }^{\mathrm{a}} \mathrm{U} / \mathrm{L},{ }^{\mathrm{b}} \mathrm{mg} / \mathrm{dL},{ }^{\mathrm{c}} \mathrm{mmol} / \mathrm{L},{ }^{\mathrm{d}} \mu \mathrm{mol} / \mathrm{L}$ per 30 $\min . \mathrm{ALP}=$ alkaline phosphatase; $\mathrm{AST}=$ aspartate aminotransferase; ALT = alanine aminotransferase; $\gamma$-GTP = gamma-glutamyl transpeptidase; LDH = lactate dehydrogenase; $\mathrm{BUN}=$ blood urea nitrogen; MDA $=$ malondialdehyde. ${ }^{*} \mathrm{P}<0.05,{ }^{\star *} \mathrm{P}<0.01$ and ${ }^{* \star \star} \mathrm{P}<0.001$ compared with the control group. other apical membrane enzymes, such as lactase, maltase and alkaline phosphatase, were not changed between both groups. The acute administration of MCLR also produced a significant increase in the activity of acid phosphatase and succinate dehydrogenase, marker enzymes for lysosomal and mitochondrial membranes, respectively.

Lipid peroxidation levels.- Results on lipid peroxidation revealed a significant increase in levels of MDA in both serum (Table I) and intestinal homogenate (Table II) from MCLR-treated rats compared to control rats, suggesting that the peroxidative status was modified after administration of this toxin.

\section{Discussion}

As previously observed in rats (19), mice (9) and fish (15), the present study reports damage to the liver in MCLRtreated rats. Increased organ weight of the liver (results not shown), together with

Table II. Enzyme activities and lipid peroxidation level in intestinal homogenates from control and MCLR-treated rats.

\begin{tabular}{lcc}
\hline Parameter & Control & MCLR-treated \\
\hline Sucrase & $20 \pm 1$ & $30 \pm 3^{*}$ \\
Lactase & $8 \pm 1$ & $10 \pm 2$ \\
Maltase & $389 \pm 29$ & $411 \pm 41$ \\
ALP & $263 \pm 31$ & $266 \pm 32$ \\
ACP & $19 \pm 2$ & $28 \pm 3^{*}$ \\
SDH & $1205 \pm 112$ & $3027 \pm 501^{* *}$ \\
MDA & $0.3 \pm 0.01$ & $0.4 \pm 0.02^{* *}$ \\
\hline
\end{tabular}

Values are means \pm SE for six different preparations. All enzyme activities are expressed in $\mathrm{nmol} / \mathrm{mg}$ protein per min. ALP, alkaline phosphatase; ACP, acid phosphatase; SDH, succinate dehydrogenase. Malondialdehyde (MDA) production is expressed in $\mathrm{nmol} / \mathrm{mg}$ protein per 30 min. ${ }^{*} \mathrm{P}<0.05$ and ${ }^{* *} \mathrm{P}<0.01$ compared with the control group. 
abnormally high serum ALP levels, and significantly enhanced transaminases (AST, ALT) and LDH activities, reflects the necrosis of hepatocytes, with release of enzymes and subsequent large elevations in serum enzymes. Our results suggest that $\gamma$-GTP activity may not be a suitable indicator of hepatic damage from acute exposure to MCLR, since no changes were observed between control and treated rats. In addition, these changes are similar to those observed in rats after ingestion of microcystin-containing cyanobacteria in drinking water, although in this case the levels of AST and ALT were not altered (10).

A number of significant changes in serum chemistry was reported in rats treated with microcystin. As previously shown by FAWELL et al. in mice (9), reductions in serum albumin and total protein were observed in MCLR-treated rats when compared to control rats. Furthermore, cholesterol and triglyceride levels were diminished in treated rats, reflecting liver damage. In contrast, elevated serum glucose was found in rats after administration of MCLR due to the activation of phosphorylase a (the rate-limiting enzyme for glycogenolisis), with the subsequent depletion of glycogen stores and alteration in carbohydrate metabolism (19).

Studies on electrolyte levels in serum showed a decrease in the content of sodium, potassium, calcium and phosphorus, which could be due to a reduction of the renal absorption induced by the toxin, as previously observed by NOBRE et al. in isolated perfused rat kidney (20).

A number of reports have shown the effects of MCLR on the liver. On the contrary, this is the first report concerning the effects of MCLR on rat intestinal function. The apical membrane enzymes are membrane-bound glycoproteins located on the brush-border surface of the intestinal enterocyte, being responsible for the final stages of digestion. Among the apical membrane enzymes studied, only sucrase was affected by the treatment with MCLR, whereas lactase, maltase and alkaline phosphatase were not modified between both groups of animals. Moreover, the specific activities of acid phosphatase and succinate dehydrogenase, respective markers for lysosomal and mitochondrial membranes, were significantly increased after the treatment with MCLR. These results are in agreement with previous studies reporting functional changes in lysosomal and mitochondrial hepatic membranes from rodents treated with microcystins $(11,18)$.

The determination of lipid peroxidation levels in intestinal mucosa showed that the peroxidative status was significantly increased in MCLR-treated rats when compared to control animals. Despite the TBARS procedure constituting an indirect way of measuring lipid peroxidation, which is susceptible to interference with endogenous and exogenous substances, it has been the method of election in many studies. Nevertheless, the values of TBARS analyses should be regarded as an index rather than as an absolute measurement of total tissue lipid peroxide levels. TOwNer et al. (23) also observed an enhancement in liver lipid peroxides following acute exposure of MCLR in rats, suggesting that oxidative stress is involved in in vivo microcystininduced hepatotoxicity in mammals, and may play a significant role in the pathogenesis of MCLR-induced toxicity. Among the reactive oxygen species (ROS), superoxide radical $\left(\mathrm{O}_{2}{ }^{-}\right)$and hydrogen peroxide $\left(\mathrm{H}_{2} \mathrm{O}_{2}\right)$ were involved in the toxicity of MCLR in primary cultured hepatocytes (6). Therefore, the observed increase in the production of 
oxygen free radicals in the intestine of MCLR-treated rats could contribute to intestinal damage (14), with alteration in cellular membrane organization, membrane fluidity and modification in the activity of intestinal membrane enzymes. In this sense, the fluidity of hepatic microsomal membranes from mice (11) and hepatic mitochondrial membrane from rats (18), has been reported to be affected by the exposure to MCLR.

In conclusion, our results suggest that exposure to MCLR in rats alters intestinal peroxidation levels as well as the activity of cellular membrane enzymes. It is not clear whether the effects of MCLR involve a direct interaction with the membranes or there is an indirect secondary effect to changes in the mucosa peroxidation levels induced by the toxin. In addition, the observed changes in the intestine of treated-rats might be effects of hypovolemic shock secondary to massive liver injury, as previously observed (19). More studies on isolated cellular membranes are necessary to elucidate the precise mechanism(s) involved in the reported effects of MCLR.

\section{Acknowledgements}

This work was supported by grants from Junta de Andalucía (CTS-257 and CTS-358). The authors are grateful to Dr. Morán (University Hospital Puerto Real, Cádiz, Spain) for helping with serum determinations.

I. M. MORENO, A. MATE, G. REPETTO, C. M. VÁZQUEZ y A. M. CAMEÁN. Influencia de la Microcistina-LR sobre la actividad de enzimas de membrana en mucosa intestinal de rata. J. Physiol. Biochem., 59 (4), 293-300, 2003.

En este trabajo se analiza la acción de la toxina microcistina-LR (MCLR) sobre la actividad de diversas enzimas de membrana en la mucosa intestinal. Para ello, se utilizan ratas
Wistar a las que se inyecta por vía intraperitoneal $100 \mu \mathrm{g}$ MCLR/Kg peso corporal o bien solución salina (grupo control). Asimismo, se realiza un estudio bioquímico en suero, y se determina el grado de peroxidación lipídica en la mucosa intestinal y suero de estos animales tras el tratamiento con MCLR. La toxina induce daño hepático severo en las ratas tratadas, como lo demuestra el aumento del peso del hígado y diversas alteraciones de las enzimas hepáticas en suero. Por lo que respecta a las enzimas de membrana, las ratas tratadas con MCLR presentan un aumento en la actividad de la enzima sacarasa en la mucosa intestinal, no alterándose otras enzimas apicales como la lactasa, maltasa o fosfatasa alcalina. MCLR también produce un aumento en la actividad de la fosfatasa ácida y succinato deshidrogenasa, marcadores respectivos de membranas lisosomales y mitocondriales. Además, los niveles de peroxidación lipídica en suero y mucosa intestinal aparecen anormalmente elevados tras el tratamiento, como consecuencia de la producción excesiva de radicales libres de oxígeno inducida por la toxina. Por consiguiente, la intoxicación aguda con MCLR afecta a la fisiología intestinal provocando una modificación del estado peroxidativo y alterando la actividad de las enzimas de membrana intestinales.

Palabras clave: Microcistina-LR, Intestino, Rata, Enzimas de membrana.

\section{References}

1. Absolom, D. R. (1986): Methods Enzymol., 132, 95-180.

2. Bradford, M. M. (1976): Anal. Biochem., 72, 248254.

3. Bretaudiere, J. P., Vassault, A., Amsellem, L., Pourc, M. L., Thieu-Phung, H. and Bailly, M. (1977): Clin. Chem., 23, 2263-2274.

4. Camean, A., Reinhardt, K., Humment, C. and Luckas, B. (1997): J. Vet. Pharmacol. Ther., 20, 282-283.

5. Dahlqvist, A. (1964): Anal. Biochem., 7, 18-25.

6. Ding, W. X., Shen, H. M. and Ong, C. N. (2001): J. Toxicol. Environ. Health A, 64, 507-519. 
7. Esterbauer, H. and Cheeseman, K. H. (1990): Methods Enzymol., 186, 407-421.

8. Falconer, I. R., Dornbush, M., Moran, G. and Yeung, S. K. (1992): Toxicon, 30, 790-793.

9. Fawell, J. K., Mitchell, R. E., Everett, D. J. and Hill, R. E. (1999): Human Exp. Toxicol., 18, 162167.

10. Heinze, R. (1999): Environ. Toxicol., 14, 57-60.

11. Hermansky, S. J. and Stohs, S. J. (1991): Res. Commun. Chem. Pathol. Pharmacol., 72, 213222.

12. Hooser, S. B., Kuhlenschmidt, M. S., Dahlem, A. M., Beasley, V. R., Carmichael, W. W. and Haschek, W. M. (1991): Toxicon, 29, 589-601.

13. Ito, E., Kondo, F. and Harada, K. (2000): Toxicon, 38, 37-48.

14. Kiziltunc, A., Cogalgil, S. and Cerrahoglu, L. (1998): Scand. J. Rheumatol., 27, 441-445.

15. Kotak, B. G., Semalulu, S., Fritz, D. L., Prepas, E. E., Hrudey, S. E. and Coppock, R. W. (1996): Toxicon, 34, 517-525.
16. Kuiper-Goodman, T., Falconer, I. and Fitzgerald, J. (1999): In "Toxic Cyanobacteria in Water - A Guide to Their Public Health Consequences, Monitoring and Management". (Chorus, I. and Bartram, J., eds.). London: E\&FN Spon (for the World Health Organization). pp. 113-153.

17. Lankoff, A. and Kolataj, A. (2001): Toxicon, 39, 419-423.

18. Miura, G. A., Robinson, N. A., Geisber, T. W., Bostian, K. A., White, J. D. and Pace, J. G. (1989): Toxicon, 27, 1229-1240.

19. Miura, G. A., Robinson, N. A., Lawrence, W. B. and Pace, J. G. (1991): Toxicon, 29, 337-346.

20. Nobre, A. C., Jorge, M. C., Menezes, D. B., Fonteles, M. C. and Monteiro, H. S. (1999): Brazil. J. Med. Biol. Res., 32, 985-988.

21. Pennington, R. J. (1961): Biochem. J., 80, 649652.

22. Runnegar, M. T., Gerdes, R. G. and Falconer, I. R. (1991): Toxicon, 29, 43-51.

23. Towner, R. A., Sturgeon, S. A. and Hore, K. E. (2002): Free Radical Res., 36, 63-71. 